\title{
'The heart of what we do': policies on teaching, learning and assessment in the Learning and Skills Sector
}

By Ian Finlay ${ }^{\star}$, Ken Spours^, Richard Steer^, Frank Coffield^, Maggie Gregson+, and Ann Hodgson^

*University of Strathclyde

Anstitute of Education, University of London

+ University of Sunderland

Corresponding author; Ian Finlay, Department of Educational and Professional Studies, University of Strathclyde, Jordanhill Campus, 76 Southbrae Drive, Glasgow, G13 1PP i.j.finlay@strath.ac.uk

Submitted for special issue of JVET for ESRC TLRP project: The impact of policy on learning and inclusion in the learning and skills sector. 


\begin{abstract}
One of the stated aims of government policy in England is to put teaching, training, and learning at the heart of the learning and skills system. This paper provides a critical review of policies on teaching, learning and assessment in the learning and skills sector over the past five years. It draws upon data collected and analysed in the early stages of an ESRC-funded Teaching and Learning Research Programme project $^{1}$.
\end{abstract}

Using evidence from policy sources, we argue that despite policy rhetoric about devolution of responsibility to the 'front line', the dominant 'images' that government has of putting teaching, learning and assessment at the heart of the Learning and Skills Sector involves a narrow concept of learning and skills; an idealisation of learner agency lacking an appreciation of the pivotal role of the learner/tutor relationship and a top-down view of change in which central government agencies are relied on to secure education standards. 


\section{Aim of the Paper}

The aim of this paper is to explore government assumptions of, and actions towards, teaching, learning, and assessment (TLA) in the Learning and Skills Sector (LSS) in England through an analysis of major policy and grant documents. The LSS in England comprises all post-sixteen education and training except that designated higher education. One may criticise the direction, quantity or speed of government policy on post-compulsory education and training, but it would be difficult to doubt the commitment of the current government to the sector. It will be argued that government actions result in a highly centralised and micro-managed LSS within a context of increasing rhetoric about, and organisational changes towards, more devolved governance. It appears that this government is still ambivalent about the extent to which providers can be trusted to meet the needs of learners, although the recent challenge to the sector to come up with its own ideas about self-regulation by Alan Johnson, the Secretary of State, in his speech at the Association of Colleges Annual Conference in Birmingham in November 2006, may possibly mark a change in direction.

The project on which this paper is based is seeking to evaluate the impact of key national policy levers, such as funding, targets and inspection, on TLA (e.g. the provision of learning opportunities, learner outcomes and motivation in the new LSS). It is described in more detail in the introduction to the series of papers in this issue of JVET.

\section{Approaches to Policy}

Since 2000 there has been a steady stream of policy texts emanating from the relevant departments that have served to define the LSS and the government's 
priorities for the sector. Examples of such documents are the Learning and Skills Council Remit Letter (DfEE, 2000a), Skills for All (DfEE, 2000b) Success for All (DfES, 2002a) and Further Education: Raising Skills, Improving Life Chances (DfES, 2006a).

Policy is a loose term. Here it is used to cover value commitments, strategic objectives, and operational instruments and structures at national, regional, local and institutional levels. The matrix in Table 1 illustrates an approach to policy that relates two different dimensions. The horizontal dimension reflects what we have termed conceptual levels of policy. The vertical dimension identifies structural levels of policy. An example of a specific policy is given in each of the cells.

\section{INSERT HERE TABLE 1 - Policy Matrix}

Table 1 illustrates two dimensions along which policy can be described. One links value commitments, strategic objectives, and operational practices and shows how these have developed over time. The second also identifies links between policies being enacted at different levels in the system and highlights possible differences between intentions and outcomes at each of the levels. In this paper we explore issues relating to the top two rows of the table. These are the rows that illustrate policy at the Ministerial/Departmental and national levels.

In addition to looking at the three horizontal dimensions at this level an attempt will be made to relate recent policy history on the LSS in England to the three elements of Kooiman's (2003) social interactionist approach to policy analysis. The relationships between his concepts of governing images, governing instrumentation, and governing actions in terms of policies impacting on TLA in the English LSS will be discussed. In this paper we interrogate a range of policy documents relevant to 
the LSS, in order to identify the governing images or value commitments, governing instrumentation or strategies, and governing actions or operations promoted by these documents.

\section{Teaching and Learning in Government Policy in the LSS $2001-2006$}

The Ideological Level: Images of Learning Reform

According to Kooiman:

'Governing is inconceivable without the formation of images. Anyone involved in governing...forms images about what he or she is governing.' (Kooiman, 2003: 29)

Kooiman discusses how images are formed; that they can be highly sophisticated and based either on a keen understanding of the system being governed or on impressions or even prejudices. These images can be explicit or they may need to be inferred from instruments or actions. The descriptions of government policies below allow us to make some claims about the images of learning and underpinning values held by the government as they attempt to reform the LSS.

David Blunkett, the former Secretary of State for Education and Employment, set out the values of the Government on learning in the LSC's first Remit Letter (DfEE, 2000a):

Learning has a major contribution to play in sustaining a civilised and cohesive society, and underpins the Government's objectives for the 
renewal of deprived neighbourhoods. Learning encourages people to develop as active citizens and to play a full part in their local community. It strengthens families, builds stronger neighbourhoods, helps older people stay healthy and active, and encourages independence for all by opening up new opportunities - including the chance to explore art, music and literature. And what was available only to the few can, in this new millennium, be enjoyed and taken advantage of by the many. (para. 5)

There are a number of discursive aspects of this extract that are worth teasing out in detail. Firstly, the extract emphasizes the civic, social, economic and individual benefits which are claimed for learning. It makes the assumption that learning always has positive social and individual outcomes, but this is an assumption that cannot be sustained in all circumstances. For example, learning can also discourage people from developing 'as active citizens' and can weaken families and neighbourhoods if, for example, it takes place in a deviant, gang culture, or if graduates move away from the localities where they were born to find jobs. The social effects of learning depend on what is learned and in what circumstances the learning takes place. It is not recognised sufficiently that learning can also increase inequalities in society.

Learning can be defined as a significant increase in understanding or capability (adapted from Burgess, 2002: 82). Learning, defined in this way, takes place in all social settings. Education is a purposive activity designed to promote learning which the group organising it deems to be worthwhile, although they may recognise that the actual learning outcomes do not always coincide with those aimed at. The minimal use of the term education in recent documents referring to the postcompulsory stage seems to be a deliberate government tactic. In our earlier work (Coffield et al., 2005; Hodgson et al., 2005; Steer et al.,2007) we identified a number 
of key policy levers (e.g. planning, funding, inspection, targets, and initiatives) used by the government in their efforts to bring about their intentions. These may be represented as 'on-stage' or 'front of house' mechanisms (Trowler, 1998). There are also ways in which behind or 'below-the-stage' mechanisms of influencing the system may be represented. Humes (2005) coined the phrase 'narrative privilege' to describe the ability of power elites to set the discursive agenda. Trowler (2001) drawing on Bowe et al. (1994) used the term 'discursive capture'. Both Trowler and Humes have in mind the ability of those in power to use language as an instrument of power, e.g. 'education' as a term has been almost completely excluded from documents on post-compulsory education and training and the phrase 'learning and skills sector' substituted ${ }^{2}$. To some extent we have colluded in this (or have been captured by the discourse) by using the concept of the learning and skills sector in the title of our project. Terms such as 'vocational education and training' or 'postcompulsory education and training' have greater international currency and are still well-understood in England.

What messages or power relationships might be implied by the replacement of the term education by learning and skills? One message, for which there exists some evidence, is that learning and skills imply a focus on the recipients rather than on the providers of the service, unlike the term education. Learning is conceived of in government texts as an individual activity, whereas education is a collective activity that is the responsibility of national government. This interpretation is supported by statements contained in government documents, e.g. "putting learners at the heart of the system' implies a clear focus on the recipients of the service. In focussing on learning rather than education, New Labour is continuing the modernisation project started by the Conservative governments between 1979 and 1997, which deliberately sought to remove power and influence from education professionals and concentrate it in the hands of central government (see e.g. Newman, 2001). 
A second interpretation for the changing language is the view in England, developed from the late 1970s, that the education system is part of the problem of economic performance. Thus re-branding the post-compulsory education system as a learning and skills sector could be seen as disassociating the government from a compromised term and passing the responsibility for learning to the individual and away from the government.

A third possible explanation of the changing discourse is to see it as a manifestation of a progressive movement in education with a focus on learning in contexts not normally associated with education (e.g. the workplace) and on student-centredness. The phrase putting 'teaching, training and learning at the heart of the system' could also be associated with such progressive concerns. One commentator on an earlier version of this paper expressed it as follows, "part of the intention in choosing an emotive term like heart was exactly to put back into the system concern for hearts as well as minds, for the emotive and the affective aspects of learning to be taken into account, to move away from a purely functional view of learning which was alienating both teachers and learners'. A different commentator with a government insider perspective argued that 'the adoption of 'learner' and 'focus on the individual learner' ...was by no means an attempt to denigrate education or the social nature of learning. Rather, it was intended to redress the false hierarchies implicit in so much educational terminology, which had ill effects on the often-disadvantaged people to whom policy was intended to bring parity of esteem'. In terms discussed earlier these are 'front of house' or 'on-stage' representations of the discourse.

Although the earlier extract from Blunkett embraces a wide view of the purposes of education, this holistic perspective is not carried through into the operational aspects of policy which focus primarily on economic objectives. The majority of initiatives and 
funding appear to be aimed at developing programmes with explicit outcomes for the economy. In his introduction to Opportunity for All: Skills for the New Economy (DfEE, 2000c) Blunkett is explicit about the economic benefits of learning.

..., skills and learning must become the key determinants of the economic prosperity and social cohesion of our country. Knowledge and skills are now the key drivers of innovation and change. Economic performance depends increasingly on talent and creativity. And in this new economy, it is education and skills which shape the opportunities and rewards available to individuals. (3)

This simplified version of human capital theory cannot be sustained. For an individual there is strong evidence that better qualifications and levels of skills lead to higher returns in the job market but this has not been demonstrated with qualifications at Level 1 which, unless used as a stepping stone to higher qualifications, may even serve to stigmatise learners. It is not possible to assert that, in every case, economies will improve their performance just by a general rise in levels of 'talent and creativity'. Economic performance depends on a wide range of both demand and supply factors, e.g. on the supply side, a talented labour force could be hampered by poor capital investment resulting in lower levels of productivity than they would achieve with better equipment. Interest rates, exchange rates, levels of savings, and the terms of trade all affect economic performance yet are not causally dependent on knowledge and skills in the naïve terms asserted above (Wolf, 2002).

The aims of government with respect to learning have been outlined above without any reference to how learning might be conceived of by policy makers. A statement in DfES (2003) gives us one insight into this. 
For too many people, learning is something that stops when they

leave school. Learning new skills, at work and for pleasure, must become a rewarding part of everyday life. (10)

There is an implicit acceptance of the acquisition model of learning ${ }^{3}$ in this statement. The assumption is being made that learning only takes place when there is intention on the part of the learner to 'learn new skills' and that this learning requires engagement with teachers and training providers. There needs to be transmission of knowledge or skills to the learner. In short, there is no recognition of either the constructivist (e.g. Kerka, 1997) or situated learning models (e.g. Lave and Wenger, 1991) that suggest that people cannot fail to be learning and that learning is quintessentially social. Those who support such models of learning would suggest that it is an integral part of living and occurs as people participate in the daily round of work, leisure and other activities. One of the difficulties with the latter models of learning for policy makers is that they place such forms of learning outside the direct control of policy and outside institutional forms of education.

At the centre then of the government's image of learning is the concept that the main purpose of learning is the development of economically useful skills and that learning involves the formal acquisition of these skills. We turn now to the strategic level and the policy instruments and actions selected by government to act on the LSS.

The Strategic Level: Governing Instruments

A useful way to track the government strategy and the instruments on TLA for the learning and skills sector since 2000 is through the LSC's remit letter (DfEE, 2000a) 
and the annual grant letters (DfEE, 2000d; DfES, 2001; DfES, 2002b; DfES, 2003; DfES, 2004a; DfES,2005; DfES, 2006b).

Originally Blunkett (DfEE, 2000a) in the remit letter of over 20 pages identified an overarching aim and 'four wider objectives' for the LSC. The overarching aim was that 'The council must include at its heart strategies and plans to achieve the post-16 National Learning Targets, and ensure that the learning which it funds enhances equality of opportunity' (para. 38). The four wider objectives were:

1. Encouraging young people to stay on in learning;

2. Increasing demand for learning by adults;

3. Maximising the contribution of education and training to economic performance; and

4. Raising standards.

These are the strategic objectives of government for the LSS, which are to be met by a number of specific measures, e.g. collaboration between the LSC and Connexions (the employment and training advisory service for young people); the effective use of Education Maintenance Allowances; and the opportunity for young people to:

- 'choose education and training that will meet their needs' and take them to at least a Level 2 qualification;

- the creation of 'clear and stimulating pathways';

- 'developing links between secondary and post-16 provision'; and

- encouraging young people to 'experience the world of work'

(DfEE, 2000a, paras. $40-45$ ) 
Ways of increasing demand for learning by adults were listed as the provision of 'high quality information advice and guidance'; 'a continuing drive to improve the flexibility and attractiveness of learning opportunities'; 'the development of on-line learning opportunities'; arrangements to tackle poor basic skills including the embedding of 'literacy and numeracy support'; and collaboration with the Employment Service. (ibid., paras. 46 - 54).

The third objective above has less relevance to this paper on TLA but two of the strategies for achieving it are germane. These are raising the profile of learning in the workplace and the role of the post-16 National Learning Targets in raising the general skill level of the workforce (ibid. paras. $58 \& 60$ ).

A variety of strategies were also put forward aimed at raising standards. These included developing a close working relationship between the LSC and the Inspectorates; addressing 'unhealthy competition' between providers; 'improving the take-up of professional teaching and training qualifications'; and working 'with providers to improve their capacity to deliver lifelong learning ... objectives'. (ibid. paras. $62-69)$.

\section{INSERT HERE TABLE 2: Changing priorities}

The annual grant letters show how the emphases in policy have shifted over the years from 2000 to 2006 . Table 2 provides an example of the way priorities have changed during this period. Policy is tracked across the seven grant letters published so far. This proved to be a straightforward task for the first three letters but as the original objectives of the remit letter became superseded by new objectives contained in Skills for Life (DfEE, 2001), Success for All (DfES, 2002a), 21 ${ }^{\text {st }}$ Century Skills (DfES et al, 2003), and Five Year Strategy for Children and Learners (DfES, 
2004b), it became more difficult. What these additional policy documents did was to flesh out policies that had previously been sketchy. Policy in the LSS from Blunkett's term as Secretary of State through to the third year of Clarke's term became more detailed, more complex, but also more centrally controlled.

Table 2 illustrates the developing priorities with respect to the participation of young people. One point that is immediately apparent from this table is the increase in the number of instructions given to the LSC between the first grant letter of Blunkett and the letters of Morris and Clarke (to make the table more user friendly in some cases two points in the letters have been collapsed into one so the increase is even more acute than is illustrated). By contrast Johnson's letter sets far fewer objectives. There is a very clear change in tone between the early grant letters of Blunkett and Morris and the later letters of Clarke. The former are businesslike and professional as though addressing a respected agent. Clarke's letters are much more authoritarian and hectoring in tone. Blunkett, for example, wrote 'Your key achievement areas...are:' (DfEE, 2000d). This was followed by a list of priorities. Clarke's third letter is full of statements like 'The Council must...', and 'I look to [the Council] to drive forward...'. Motoring metaphors are frequent for example, 'drive forward', 'driving up', 'step up a gear', 'keep up momentum', and 'an acceleration of improvement' (DfES, 2004a). The letters of Kelly and Johnson (DfES, 2005; DfES, $2006 \mathrm{~b})$ revert towards the more measured tones of earlier letters but retain the assumption of a need for a step-change. One possible reason for the tone of the Clarke grant letters was the anxiety that the 'early LSC model' in the period up to 2003 (Hodgson et al. 2005), was not delivering the change that government expected of the LSS. As well as the perennial need for politicians to show immediate results, the grant letters may have reflected a desire for the LSC to embrace what ministers saw as a more responsive 'business cycle model' (Steer et al. 2007). The 'Agenda for Change' reforms under Mark Haysom appear to have succeeded in calming 
ministerial nerves and this may have been reflected in the character of the more recent grant letters from Kelly and Johnson.

Over and above the issue of tone, there were several significant shifts in policy over the seven grant letters. While encouraging young people to participate in education remained a constant theme, the measures to achieve this altered. The Blunkett letter still envisaged a 16-19 stage. Morris wrote of both 16-19 and 14-19. By the time of Clarke the discourse had completely moved to 14-19. Kelly's letter recognised the proposals in the LSC's Agenda for Change and anticipated the changes that would arise from the Foster Review of FE, the Leitch Review of Skills and the work of the new Quality Improvement Agency. Over the period of the letters some programmes stayed the course, some disappeared and new programmes were introduced. For example, modern apprenticeships (now called apprenticeships) were introduced before the LSC was set up and continue, with the possibility of being extended to 14 year olds and adults. The take up of Curriculum 2000 qualifications was encouraged by Morris in 2001 but never mentioned thereafter. Entry to Employment (E2E), Employer Training Pilots (ETP) later becoming Train to Gain, and Education Maintenance Allowances (EMAs) are all examples of new initiatives.

The big issues remained the same. These were improving participation and achievement of both adults and young people; addressing literacy and numeracy needs in both adults and young people; raising the standards of both teaching and learning; and promoting equal opportunity and diversity. These objectives were addressed in several of the policy documents referred to above and it was these documents which were listed as key policy texts by most of those we interviewed. 
Adult literacy and numeracy skills are addressed in Skills for Life (DfEE, 2001). In the Foreword, Blunkett lists some of the measures that were taking place:

We are investing in high quality training and support for teachers and in the tools they need to do their job - consistent national standards, a common core curriculum, relevant materials and new National tests which will be the benchmark for all literacy and numeracy achievement. (1)

The policies contained in the document include researching ways of motivating learners, identifying different teaching methods, improving assessment, developing teachers, and introducing a rigorous inspection regime. An unstated aim seems to have been to create a teacher-proof curriculum. A possible tension appears on page 3, 'research projects in each part of the country will explore different ways of motivating learners, meeting their specific needs and helping them acquire new reading, writing and number skills as quickly as possible.' (DfEE, 2001). The next paragraph describes the production of 'New national standards, new materials and a common core curriculum leading to National Tests [which] will make sure that the same approach to teaching and learning, based on the most effective practice, is adopted across the country' (ibid.). Thus before the research was undertaken, a range of operational measures were put into place that make assumptions about what might work. What if the research had indicated that the success in motivating learners to meet their specific needs relies on local cultural and contextual factors, as research by Hodkinson et al. (2004) indicates? What then is the point of new nationally promoted materials and approaches? There are sound philosophical and psychological arguments against attempting to promote a common strategy supported by common materials and teaching methods in an attempt to meet the 'specific needs' of a diverse group of learners (see e.g. Halliday, 1996). Recent work 
by the Standards Unit seems to be taking on board more sophisticated models of support and development, e.g. involving teachers working collaboratively with coaches to improve their practice, and it will be interesting to see the independent evaluations of these measures.

The next major policy document relevant to TLA was Success for All: Reforming Further Education and Training, (DfES, 2002a) which was a response to inspection reports that identified, among other things, 'widely divergent standards of learner achievement' (ibid.4). The strategy to tackle this and related problems has four elements, each of which received mention from some of our interviewees. These elements were:

- $\quad$ 'Meeting needs, improving choice by improving the responsiveness and quality of provision in each area to meet learner, employer and community needs;

- $\quad$ Putting teaching, training and learning at the heart of what we do by establishing a new Standards Unit to identify and disseminate best practice, which will guide learning and training programmes;

- Developing the leaders, teachers, lecturers, trainers and support staff of the future including setting new targets for full and part-time college teachers to be qualified, and developing strong leadership and management through a new leadership college; and

- Developing a framework for quality and success by establishing a new planning, funding and accountability system, based on greater partnership and trust, including thee year funding agreements. (ibid. 5)

Success for All thus clearly completes the trajectory from ideological commitments through strategic objectives to operational instruments and structures. In the 
foreword, the Secretary of State reiterates the government's commitment to social justice and economic success. The four bullet points above indicate strategic objectives in the statements in bold lettering and then outline the operational practices and instruments that will be used to achieve them. In the final chapter of Success for All, implementation through the structural levels is partly addressed. The greatest emphasis is on what will be done at the ministerial and national levels but there are also milestones to be achieved by LLSCs (e.g. conducting Strategic Area Reviews, StARs) and colleges (e.g. trialling new teaching and learning materials).

Some steering mechanisms proposed in this document are similar to those proposed in Skills for Life, for example teacher, trainer and lecturer development, and the identification and dissemination of 'best practice' and indeed 'build[ing] on the experience of the adult basic skills strategy' (12) is an explicit aim of Success for All in its efforts to 'put teaching and learning at the heart of what we do'.

$21^{\text {st }}$ Century Skills (DfES et al., 2003) was the next major policy document on the LSS, produced this time not just by the DfES but also by the Treasury, the Department of Trade and Industry, and the Department for Work and Pensions. The signatures of the Prime Minister and Chancellor of the Exchequer are joined by those of the Secretaries of State of the above departments to emphasize the document's importance. Once again the government's commitment to 'the interdependence of social justice and economic success' (ibid., 11) was reiterated. Key strategic objectives relating to teaching and learning included supporting 'many more learners to re-engage in learning' and 'mak[ing] colleges and training providers more responsive to employers' and learners' needs' (ibid., 10). Two major operational means of achieving these strategic objectives were proposed - 
'reforming the qualifications framework' and 'raising the effectiveness of further education colleges and training providers' (ibid. 14).

Chapter 4 of this document contains a discussion about the relationships between skills development for economic objectives and learning for personal and social purposes. Both are recognised as legitimate goals of government policy, but economic goals are given priority. A clear rationale is provided - without economic inclusion, social exclusion is likely to be 'compounded', so social and economic purposes of learning are 'intertwined'. An important question for an evaluation of government policy is to what extent each of these purposes is addressed in the outcomes of policy, particularly when the needs are so wide and the resources limited.

In 2004 the DfES published its Five Year Strategy for Children and Learners (DfES, 2004b) which took matters forward in two main ways. Firstly the documents cited above were all focused on aspects of the LSS. The Five Year Strategy offers a comprehensive view of educational policy from early years through to adult learning. It is a document about lifelong learning. Its second major contribution was the central role given to 'personalisation':

This [personalisation] is not a vague liberal notion about letting people have what they want. ... The system must be both freer and more diverse - with more flexibility to help meet individual needs; and more choices between courses and types of provider, so that there really are different and personalised opportunities available. (Foreword)

Personalisation was taken up in the White Paper on FE (DfES, 2006) and is a key element of the government's wider strategy of public sector reform (Prime Minister's 
Strategy Unit, 2006), as well as the subject of a current consultation process (DfES, 2006). It focuses on the service receivers (i.e. learners), which is appropriate, but neglects the professionals within the service who constitute another important stakeholder constituency.

The rest of the Five Year Strategy details proposals of structural changes to create such a system. Clarke's introduction concludes with a call for both local and central government to 'move away from direction towards an enabling and empowering role' (DfES, 2004b: 4). Were this to come about, it would represent the reversal of a 20 year trend of increasing centralisation in education but there is little evidence in our fieldwork to suggest that education professionals are being freed from central control. The tension is between greater freedom and greater regulation. Clarke's third grant letter cited above hardly provided a ringing endorsement of greater freedom

Chapters 6 and 7 are particularly relevant to this paper. Chapter 6, '14-19 Education and Training', sets out the goal for this group which is 'Every young person to be well-equipped for adulthood, skilled work and further learning'. There are a number of references in this chapter to TLA including an indication that the Tomlinson ${ }^{4}$ proposals would be judged by the extent to which they managed to reduce the 'assessment burden'; an intention to promote a 'greater emphasis on work-related learning'; and an expanded '14 -19 offer for those who are disengaged from learning'. Chapter 7, 'Adult Skills', concentrates on the 'lack of skills at Level 2' and 'the large number of adults who lack skills in literacy and numeracy.' Policies aimed at addressing these concerns included Employer Training Pilots (now rolled out as the Train to Gain programme, bringing employers and Union Learning Representatives more centre stage), and adult basic skills provision. 


\section{Conclusion: Learning and teaching at the heart of the system?}

In this discussion of the different dimensions of policy on TLA in the LSS we have highlighted three dominant images of learners and learning reform at the ideological level:

- $\quad$ The primary image is of a learner who gains employability skills joining the labour market. Employment is seen as the central requirement for social inclusion. What follows is the emphasis on Level 2 qualifications, which are seen as the minimum benchmark for employment in $21^{\text {st }}$ Century occupations, although the Leitch Review of Skills (2006) for the Treasury recommended that Level 3 should be the benchmark if we are to compete internationally. Other motives for learning, while not entirely ignored, are not seen as key drivers.

- $\quad$ Linked closely with this image is one of learners, rather than tutors and learners, at the heart of the system. The underlying assumption is that learners have 'pent up demand' for learning which is often frustrated by inaccessible learning or poor provision. What follows is an emphasis on creating more flexibility of learning opportunities and promoting 'personalised learning'. Our research with learners and teachers in the LSS suggests that this is a one-sided view of the learning process which downplays the centrality of the teacher/learner relationship in effective learning and the role of strong institutions. Teachers are almost invisible in the policy rhetoric or are presented as being in 'deficit'. This image can also idealise and exaggerate 'the agency of learners' and their powers to place themselves at the centre of the LSS without the essential supportive relationships with tutors.

- The third image is one of national agencies enforcing consistency of practice in TLA. What follows is a role for the LSC in purchasing provision in an area, the Inspectorates ensuring that national standards are met and the Qualifications and 
Curriculum Authority (QCA) creating national qualifications specifications. National standards rather than local diversity are assumed to have primacy and the concept of consistency is imposed from above rather than constructed in negotiation with education professionals. This tension between centrally imposed standards and local innovation is repeated in other public services (see Newman, 2001).

These images strongly influence the kind of instruments that are used to steer the sector. Key targets for the LSS focus on the achievement by learners of Level 2 qualifications as the threshold for employment. Funding is skewed towards provision with employment outcomes. Initiatives such as the Employer Training Pilots were initially focused on sub-level 2 learners. Support mechanisms such as Standards Unit provision stress the universal application of what is deemed to be 'best' or 'good practice'. As a result some of the theoretical tensions that Kooiman outlines are exemplified in the workings of the English LSS. When framing governing instruments, administrations are faced with three challenges - how to cope simultaneously with a dynamic environment; with diversity; and with complexity.

Instruments to deal with dynamism require strong and accurate feedback systems. One of the weaknesses of recent policy in the LSS is the failure by government to wait long enough to allow informed feedback to reach them. There must be a temptation for them to act on the impressions of advisers or react to short-term media issues, instead of waiting to consider feedback from those who implement or 'deliver' policy. In fact there is no official feedback loop within the sector that allows policy makers to get a good grip on what is happening at the 'front line'.

Dealing with diversity, according to Kooiman, requires a careful balance of equity and responsiveness to local needs. The government has a strong rhetoric of decentralisation, which seems to accord with the current European focus on the 
principle of subsidiarity, yet seems unable to trust local administrations and providers with the type of flexibility of funding and control over their own initiatives that would enable this rhetoric to be realised in practice. Even teachers have come to be regarded as 'deliverers' of nationally produced materials through nationally identified processes rather than as actors who develop important educational relationships with students, adapt specific practices to particular contexts and who are themselves capable of innovation. Quality of practice is 'assured' by external inspection by national bodies rather than through professional trust and local accountability, although there is to be a move towards more imposed self evaluation (LSC, 2005).

The LSS is extraordinarily complex, yet it is being steered by simplistic and blunt instruments. This results in what we term 'rattlesnake farming', a metaphor derived from the practice of several states in the USA to offer bounties for rattlesnake tails in order to reduce the population of what were considered pests. Some entrepreneurial individuals started to farm the snakes to collect the bounties. In a similar way, crude targets, for example for meeting level 2 qualifications, can be 'farmed' by providers who concentrate on those learners who can easily achieve these to the exclusion of learners with greater needs.

Government actions are heavily influenced by whoever happens to be in the position of leadership. Until recently, the LSS was faced with two sources of leadership, each of whom appeared to have a different image of what the sector should look like. On the one hand, there was the DfES with an emphasis on planned provision and local collaboration: on the other hand, the Number 10 Policy Unit with an agenda of centralisation as well as local diversity and competition. In six years there have been five Secretaries of State for Education and Skills. The analysis of the grant letters illustrates differences in emphasis and approach and this in a period of administration by the same political party. 
The image promoted in the early years of the Labour administration was of creating a stakeholder society. By the rhetoric of putting teaching and learning at the heart of the sector one might have expected that teachers and learners would be considered key stakeholders in the LSS. Rather what has emerged in the governance of the LSS is a complex mix of three policy-making models (Raffe and Spours 2007):

Politicised - policy is driven to a large extent by politically informed targets which legitimates far reaching interventions in the LSS by No 10, the Treasury and Ministers.

Traditional bureaucratic in the classical Weberian framework - control is located at the centre through a carefully constructed hierarchy with tightly framed rules and procedures governing the roles of each level.

Devolved and collaborative - at the same time, there are moves to create devolved delivery partnerships at regional and local levels.

Our argument is that presently the first two models dominate the third. Clear examples of the first model include the imposition of city academies on some local authorities by the Prime Minister's policy advisers against local resistance; and the fact that the Leitch Review of Skills was driven by the Treasury, not by the Department for Education and Skills. With respect to the first of these examples, we have evidence of this policy cutting right across a strong, locally generated partnership that underpinned coordinated delivery of post-compulsory education. In our early interviews with officials in the Learning and Skills Council, we had several comments about the extent of the 'micro-management' of the Council by DfES and of the rules applied by Local Learning and Skills Councils in their dealings with providers. This exemplifies the bureaucratic approach. Collaborative delivery models do exist sometimes even between such apparent competitors as further education 
colleges and independent providers of education and training; however these are often fragile contractual arrangements which may be jeopardised by moves towards contestability.

Putting learning and teaching at the heart of the system requires more than writing the words in the text. It requires a fundamental shift in the prevailing governing images and practices of TLA within the LSS and a rethink of the kind of instruments that would steer the system in the direction of strong relationships and empowered organisations in a culture where teachers and teaching in post-compulsory education are valued, well-resourced and supported. This seems to be envisaged in the latest LSC proposals (LSC, 2005). Only time will tell if these proposals lead to the loosening of the iron grip of centralised micro-management that has been the recent dominant mode of governance of the LSS and that the Government are able, with its partners, to declare 'together, we put learning and teaching at the heart of everything we do.' ${ }^{5}$

\section{Bibliography}

Bowe, R., Ball, S. and Gerwirtz, S. (1994) 'Captured by the Discourse? Issues and Concerns in Researching 'Parental Choice', British Journal of Sociology of Education, 15(1), 63 - 78.

Burgess, T. (2002) The Devil's Dictionary of Education. London: Continuum).

Coffield, F. \& Edward S. (forthcoming) Rolling out 'good', 'best' and 'excellent' practice. What next? Perfect practice? British Educational Research Journal

Coffield, F., Steer, R., Hodgson, A., Spours, K., Edward, S. \& Finlay, I. (2005) A new learning and skills landscape? The central role of the Learning and Skills Council. Journal of Education Policy, 20(5), 631-655.

DfEE (2000a) The Learning and Skills Council: Strategic Priorities. London, DfEE.

DfEE (2000b) Skills for All: Proposals for a National Skills Agenda: Final report of the National Skills Task Force. London, DfEE.

DfEE (2000c) Opportunity for All: Skills for the New Econom.y. London, DfEE.

DfEE (2000d) Grant Letter 2001 - 02. London, DfEE. 
DfEE (2001) Skills for Life. London DfEE.

DfES (2001) Grant Letter 2002 - 03. London, DfES.

DfES (2002a) Success for All: Reforming Further Education and Training. London, DfES.

DfES (2002b) Grant Letter 2003-2004. London, DfES.

DfES (2003) Grant Letter 2004-2005. London, DfES.

DfES (2004a) Grant Letter 2005-2006. London, DfES.

DfES (2004b) Five Year Strategy for Children and Learners,

http://www.dfes.gov.uk/publications/5yearstrategy retrieved on 29 June 2006

DfES (2005) Grant Letter: 2006-07. London, DfES.

DfES (2006a) Further Education: Raising Skills, Improving Life Chances. London, DfES.

DfES (2006b) Grant Letter: 2007-08. London, DfES.

DfES (2006c) Personalising Further Education: Developing a vision. London, DfES.

DfES, DTI, HM Treasury \& DWP (2003) $21^{\text {st }}$ Century Skills; Realising our Potential; Individuals, Employers, Nation. London, DfES.

Further Education Development Agency (1995) Learning Styles. London, Further Education Development Agency.

Halliday, J. (1996) Back to Good Teaching: Diversity within Tradition. London, Cassell.

Hodgson,A., Edward, S. \& Gregson, M. (2007) Riding the waves of policy? The case of basic skills in adult and community learning in England. Journal of Vocational Education and Training, 59(2) XXX-XXX

Hodgson, A., Spours, K., Coffield, F., Steer, R., Finlay, I., Edward, S. \& Gregson, M. (2005) A New Learning and Skills Landscape? The LSC within the Learning and Skills Sector. Research Report 1.

Hodkinson, P. et al (2004) Learning Cultures in Further Education. Paper presented at BERA Annual Conference, Manchester, September 16 - 18.

Humes, W. (2005) Do we trust our educational leaders? Teaching Scotland. Issue 15 , January. 8.

Kerka, S. (1997) Constructivism, Workplace Learning and Vocational Education. ERIC Digest No. 181.

Kooiman, J. (2003) Governing as Governance. London, Sage. 
Lave, J. \& Wenger, E. (1991) Situated Learning: Legitimate Peripheral Participation. Cambridge, Cambridge University Press.

Learning and Skills Council (2005) Learning and Skills - the agenda for change - the prospectus. Retrieved on 2 September 2005 from http://www.Isc.gov.uk/National/Documents/Keyinitiatives/agenda-forchange prospectus.htm

Leitch Review of Skills. (2006) Prosperity for all in the Global Economy: World Class Skills London, HM Treasury.

Newman, J. (2001) Modernising Governance: New Labour, Policy and Society. London, Sage.

Prime Minister's Strategy Unit (2006) The Government's Approach to Public Sector Reform. London: Cabinet Office.

Raffe, D, and Spours, K. (2007) 'Three models of policy learning and policy-making in 14-19 education' in Raffe, D. and Spours, K. (eds) Policy-making and policy learning in 14-19 Education, Bedford Way Series. London: Institute of Education.

Sfard, A. (1998) On two metaphors for learning and the dangers of choosing just one. Educational Researcher, 27(2), 4-13.

Steer, R., Spours, K., Hodgson, A., Finlay, I., Coffield, F., Edward, S, \& Gregson, M. (2007) Modernisation and the role of policy levers in the learning and skills Sector. Journal of Vocational Education and Training, 59(2) XXX-XXX

Trowler, P. (1998) Education Policy. Eastbourne, Gildredge.

Trowler, P. (2001) Captured by the Discourse? The Socially Constitutive Power of New Higher Education Discourse in the UK. Organization, 8(2), 183-201.

Wolf, A. (2002) Does education matter? Myths about education and economic growth. London: Penguin. 
${ }^{1}$ The researchers wish to acknowledge funding received from the ESRC for this project - grant number RES-139-25-0105.

${ }^{2}$ Recent discussions with policy makers suggest the most recent official description is the terms further education system, rather than learning and skills sector and system.

${ }^{3}$ Sfard (1998) discusses two metaphors of learning: the acquisition metaphor that assumes learning to be a processes of acquiring knowledge, skills or meaning and the participation metaphor that views learning as participation in social activities.

${ }^{4}$ Mike Tomlinson was commissioned by the government to lead an inquiry and make recommendations for the reform of qualifications for the $14-19$ age group.

${ }^{5}$ We are grateful to Patrick Ainley, Alan Brown, Ralph Catts, Sue Cousin, and David Sherlock who commented on an earlier version of this paper and to the two anonymous reviewers for JVET whose advice was valuable. 